\title{
The Reverse Effect of Salicylic Acid on Cd-induced Growth, Chlorophyll, and Rubisco/Rubisco Activase in Tobacco
}

\author{
Yu Shan Wang and Kwang Soo Roh* \\ Department of Biology, Keimyung University, Daegu 704-701, Korea
}

Received March 15, 2012 /Revised April 6, 2012 /Accepted April 6, 2012

\begin{abstract}
The influence of salicylic acid (SA) on growth, chlorophyll, and rubisco/rubisco activase and effect of denaturator on rubisco/rubisco activase activity were studied in tobacco plants grown in vitro with cadmium $(\mathrm{Cd})$ treatment. In order to find out the optimum concentration of SA, tobacco plants treated with $10^{-6} \mathrm{mM}-10^{2} \mathrm{mM}$ of SA were grown in MS medium for 9 weeks, respectively. The most pronounced effect on in vitro growth was found at $10^{-4} \mathrm{mM} \mathrm{SA}$. Among the control (not treated with $\mathrm{Cd}$ and $\mathrm{SA}), \mathrm{SA}, \mathrm{Cd}$, and $\mathrm{Cd}+\mathrm{SA}$, the growth and content of chlorophyll were in the sequence of $\mathrm{Cd}<\mathrm{Cd}+\mathrm{SA}<$ control $<\mathrm{SA}$, and significantly higher at SA compared with others. Similar results were also observed in the content and activity of rubisco and rubisco activase. These data suggest that inhibitory effect by $\mathrm{Cd}$ was reversed by SA. These results also indicate that SA has a positive effect on $\mathrm{Cd}$. The effect of denaturants on rubisco activity showed in the sequence of $\mathrm{Cd}<\mathrm{Cd}+\mathrm{SA}<$ control < SA. Rubisco activity was promoted by L-cysteine and $\beta$-mercaptoethanol, not by urea, thiourea, and guanidium- $\mathrm{HCl}$. These data suggest that urea, thiourea, and guanidium $-\mathrm{HCl}$ are able to act as denaturator, and L-cysteine and $\beta$-mercaptoethanol are not. None of the five denaturants affected the activity of rubisco activase.
\end{abstract}

Key words : Cadmium, denaturants, rubisco, rubisco activase, salicylic acid

\section{서 론}

중금속의 일종인 카드뮴 $(\mathrm{Cd})$ 은 산업화의 부산물로서 생기 는 환경오염원으로써, 자연생태계로 유입되면 인간에게 만성 중독을 유발시켜 건강을 위협할 뿐만 아니라 식물에게도 매우 유독한 것으로 알려져 있다[15]. 카드뮴은 식물의 생장에 필수 적인 원소는 아니지만 뿌리를 통해 흡수되어 액포에 고농도로 축적되면[7], 탄수화물, 단백질, 지질 및 핵산 대사의 교란 [29,40], 뿌리에서의 수분과 양분흡수 및 기타 이온들의 흡수 억제, 발생과 분화의 지연[35], 광합성, 광호흡 및 호흡을 저해 함으로써, 궁극적으로 식물의 생장을 억제시킨다[2].

Salicylic acid(SA)는 페닐알라닌으로부터 시킴산 경로를 통 해 합성되는 단순 페놀성 화합물로서, 카르복실기와 수산기를 가지고 있다. 식물에 병원체가 침입하면 저항성이 유도되어 그 후에 침입하는 동일하거나 다른 종류의 병원체에 대해 저 항성이 증가하는 식물질병에 대한 전신획득저항성을 가지고 있는 것으로 추정하고 있으며 $[1,5,32]$, 오존, 자외선, 열 스트레 스, 냉해, 가뭄, 염 스트레스에 관여한다[14,22,39].

$\mathrm{SA}$ 는 $\mathrm{ABA}$ 에 의한 성장 억제 효과를 반전시키며[28], 키네 틴. IAA, 지베렐린과 같은 식물성장 조절제와 같이 사용하면 개화를 촉진 하는 등의 효과를 나타낸다[19]. 또한 SA는 중금

*Corresponding author

Tel : +82-53-580-5207, Fax : +82-53-580-5164

E-mail : rks@kmu.ac.kr
속이온에 의한 손실효과를 개선하는 작용을 하는 것으로 알려 져 있으며[21], 특히 SA는 카드뮴의 독성을 변형시키는 능력이 있는 것으로 보고되고 있다[9]. Panković 등[25]은 광합성의 암반응에서 RuBP (ribulose 1,5-bisphosphate) 재생에 카드뭄 이 영향을 미치며, Lee와 Roh [18]는 카드뮴이 rubisco의 유도 와 활성화를 저해한다고 보고하였다. 이러한 SA와 카드뮴의 보고들은 카드뮴에 의한 엽록소 함량, rubisco와 rubisco activase의 함량과 활성의 억제가 SA에 의해 영향을 받을 수 있을 것이라는 가능성을 추측하게 한다.

이에 본 연구에서는 광합성과 관련된 물질에서 카드뮴의 효과에 대한 $\mathrm{SA}$ 의 영향을 연구하기 위해 카드뮴에 의해 유도 되는 담배 식물의 생장, 엽록소 함량, rubisco와 rubisco activase의 함량과 활성에 미치는 $\mathrm{SA}$ 의 효과와 이에 대한 변성제 의 효과를 조사하였다.

\section{재료 및 방법}

시약

식물 배양의 MS 배지는 Duchefa 회사(Haarlem, Netherland) 제품을 사용하였으며, 이외의 모든 시약은 Sigma (ST. Louis, USA)로 부터 구입하여 사용하였다.

식물재료 배양 및 생장 측정

본 실험에 사용한 식물 재료는 담배로서, $\mathrm{SA}$ 의 최적농도를 
찾기 위해 기내배양된 담배 식물의 줄기를 $3 \mathrm{~cm}$ 로 절단하여 $10^{-6} \mathrm{mM}, 10^{-5} \mathrm{mM}, 10^{-4} \mathrm{mM}, 10^{-3} \mathrm{mM}, 10^{-2} \mathrm{mM}, 10^{-1} \mathrm{mM}$, $1 \mathrm{mM}, 10 \mathrm{mM}$ 및 $10^{2} \mathrm{mM} \mathrm{SA}$ 가 각각 함유된 MS [23]배지에 3 개씩 접종하여 9 주간 배양한 후 각 농도에 따른 담배 식물의 생장을 측정하였다.

최적농도인 $10^{-4} \mathrm{mM} \mathrm{SA}$ 와 $0.2 \mathrm{mM} \mathrm{CdCl} \cdot 2.5 \mathrm{H}_{2} \mathrm{O}$ [31]를 사용하여, 대조구(SA와 카드뮴 무첨가), $\mathrm{SA}$ 처리구, 카드맘 처리구 및 카드뮴과 SA 혼합구로 구성된 MS배지 상에 각각 기내 배양된 $3 \mathrm{~cm}$ 의 담배식물 줄기를 치상하여 배양하였다. 11 주 후, 4 개 실험구들의 생장을 측정하였고, 잎을 사용하여 엽록소 함량 및 rubisco와 rubisco activase의 함량과 활성을 측정하였다.

\section{엽록소의 함량 측정}

엽록소 함량의 측정은 Inskeep과 Bloom [13]의 방법에 의 해, 담배 식물 잎을 $5^{\circ} \mathrm{C}$ 에서 $\mathrm{DMF}$ 용액에 하루 밤 동안 정치한 후, 추출물을 $8,000 \times g$ 에서 5 분간 원심분리하였다. 상등액을 $664.5 \mathrm{~nm}$ 와 $647 \mathrm{~nm}$ 에서 흡광도를 측정하여 아래의 식으로 엽록소 $\mathrm{a}$ 와 $\mathrm{b}$ 의 함량을 계산하였다.

$$
\begin{aligned}
& \text { 엽록소 } \mathrm{a}(\mathrm{mg} / \mathrm{g} \mathrm{fw})=12.70 \mathrm{~A}_{664.5}-2.79 \mathrm{~A}_{647} \\
& \text { 엽록소 } \mathrm{b}(\mathrm{mg} / \mathrm{g} \mathrm{fw})=20.70 \mathrm{~A}_{647}-4.62 \mathrm{~A}_{664.5}
\end{aligned}
$$

\section{Rubisco의 분리}

Wang 등[42]의 방법을 이용하여 담배 식물 잎에서 rubisco 와 rubisco activase가 함유된 용액을 분리하였다. 액체 질소를 가하여 마쇄한 잎 분말 $(20 \mathrm{~g})$ 에 grinding buffer $(50 \mathrm{mM}$ BTP $\mathrm{pH}$ 7.0, $10 \mathrm{mM} \mathrm{NaHCO}_{3}, 10 \mathrm{mM} \mathrm{MgCl}, 1 \mathrm{mM}$ EDTA, 0.5 mM ATP, $10 \mathrm{mM}$ DTT, $1 \mathrm{mM}$ PMSF, $1 \mathrm{mM}$ benzamidine, $0.01 \mathrm{mM}$ leupeptin, $1.5 \% \mathrm{PVPP}, 3 \mathrm{mM} \mathrm{MBT}$ )를 첨가하여 $4{ }^{\circ} \mathrm{C}$ 에 교반하면서 4 겹의 거즈와 1 겹의 miracloth로 여과한 여과 액을 $16,000 \mathrm{rpm}$ 에서 40 분간 원심분리 하였다. 상등액에 solid $\left(\mathrm{NH}_{4}\right)_{2} \mathrm{SO}_{4}$ 를 포화 농도가 $35 \%$ 가 될 때까지 천천히 가하면서 $4^{\circ} \mathrm{C}$ 에서 30 분간 교반하였고, $8,000 \mathrm{rpm}$ 에서 8 분간 원심분리하 여 상등액과 침전물로 분리하였다.

상등액에 포화 농도가 $55 \%$ 가 될 때까지 solid $\left(\mathrm{NH}_{4}\right)_{2} \mathrm{SO}_{4}$ 를 천천히 가하면서 $4^{\circ} \mathrm{C}$ 에서 30 분간 교반한 후, $8,000 \mathrm{rpm}$ 에서 8 분간 원심분리하여 얻어진 침전물에 dissolving buffer 용액 (50 mM tricine (pH 8.0), $10 \mathrm{mM} \mathrm{MgCl}, 10 \mathrm{mM} \mathrm{NaHCO}$, $10 \mathrm{mM} \mathrm{DTT}, 2 \mathrm{mM} \mathrm{MBT}) 5 \mathrm{ml}$ 를 가하고, $17 \%$ 가 되게 $50 \%$ (w/v) PEG-10K을 첨가하여 $4{ }^{\circ} \mathrm{C}$ 에서 5분간 교반하였다. 8,000 $\mathrm{rpm}$ 에서 8 분간 원심분리한 침전물에 $\mathrm{DBR}$ 용액을 다시 넣고 다시 한번 $8,000 \mathrm{rpm}$ 에서 8 분간 원심분리 하였다. 얻어진 상등 액을 $20 \mathrm{mM}$ tris (pH 7.5)로 평형화시킨 Q-Sepharose column 에 loading한 후, 0.1-0.5 M NaCl 용액으로 $2.5 \mathrm{ml}$ 씩 용출하여 rubisco를 분리하였다.

\section{Rubisco activase의 분리}

Rubisco의 분리 방법 중, $35 \%\left(\mathrm{NH}_{4}\right)_{2} \mathrm{SO}_{4}$ 처리 후 $8,000 \mathrm{rpm}$ 에서 8 분간 원심분리하여 얻어진 침전물에 dissolving buffer 용액(20 mM BTP (pH 8.0), $0.2 \mathrm{mM} \mathrm{ATP,} 10 \mathrm{mM} \mathrm{MgCl}$, 2 $\mathrm{mM} \mathrm{MBT)} 5 \mathrm{ml}$ 로 현탁하고, 최종농도가 $18 \%$ 가 되게 $50 \%$ $(\mathrm{w} / \mathrm{v})$ PEG- $10 \mathrm{~K}$ 를 가하여 $4^{\circ} \mathrm{C}$ 에서 5 분간 교반하였다. 8,000 $\mathrm{rpm}$ 에서 8 분간 원심분리하여 얻은 침전물을 $2.5 \mathrm{ml} \mathrm{DBA}$ 용액 으로 현탁하고 $10,000 \mathrm{rpm}$ 에서 10 분간 원심분리하였다. 이 과 정을 반복하여 얻어진 상등액을 모아 Q-sepharose column에 loading하여 $20 \mathrm{mM} \mathrm{BTP}$ (pH 7.0) 용액으로 세척한 후, 0-0.5 $\mathrm{M} \mathrm{NaCl}$ 용액으로 $3 \mathrm{ml}$ 씩 용출하여 rubisco activase를 분리하 였다.

모든 분리과정은 $4^{\circ} \mathrm{C}$ 에서 수행하였으며, 분리한 rubisco와 rubisco activase 용액은 $-80^{\circ} \mathrm{C}$ 에 저장하였다.

\section{Rubisco와 rubisco activase의 함량 측정}

Rubisco와 rubisco activase의 함량은 ELISA로 측정하였 다. Microplate well에 $0.1 \mathrm{M}$ sodium carbonate-bicarbonate buffer (pH 9.5) 용액으로 희석된 효소 용액을 넣은 후, $4^{\circ} \mathrm{C}$ 에 서 하루 밤 동안 반응시키고, $0.05 \%$ Tween 20이 함유된 0.01 M PBS (pH 7.4) 용액으로 세척하였다. $0.01 \mathrm{M} \mathrm{PBS} \mathrm{(pH} \mathrm{7.4)}$ 로 만든 $0.1 \% \mathrm{BSA}$ 용액을 사용하여 blocking시킨 후, 1 차 항 체로서 토끼 항 rubisco와 항 rubisco activase 항혈청을 각각 가하고, 2 차 항체로서는 $0.1 \% \mathrm{BSA}$ 가 들어있는 $0.01 \mathrm{M} \mathrm{PBS}$ (pH 7.4)로 1:20,000 희석시킨 peroxidase-conjugated goat anti-rabbit IgG 용액을 가하였다. Peroxidase의 기질로서 $30 \% \mathrm{H}_{2} \mathrm{O}_{2}$ 가 함유된 $0.05 \mathrm{M}$ citrate/0.1 M sodium phosphate buffer ( $\mathrm{pH}$ 5.0)로 만든 OPD tablet 용액을 가하여 암 상태의 실온에서 20 분간 반응시킨 후, $1 \mathrm{~N} \mathrm{HCl}$ 로 반응을 정 지시켰다. ELISA microplate reader (Bio-Rad model 3550-UV)를 사용하여 $492 \mathrm{~nm}$ 에서 이들의 흡광도를 측정하 여 함량을 계산하였다.

\section{Rubisco의 활성 측정}

Racker [26]의 방법으로 rubisco의 활성을 측정하였다. $1 \mathrm{M}$ Tris (pH 7.8), 0.006 M NADH, 0.1 M GSH, 0.5 $\mathrm{M} \mathrm{KHCO}_{3}$, $0.5 \%$ glyceraldehyde 3-phosphate dehydrogenase, $0.025 \%$ 3-phosphoglycerate kinase, $0.05 \%$ a-glycerophosphate dehydrogenase-triose phosphate isomerase, $0.025 \%$ ribulose bisphosphate, $0.2 \mathrm{M} \mathrm{ATP}$ 및 $0.5 \mathrm{M} \mathrm{MgCl}_{2}$ 로써 조제한 측정용액 $0.94 \mathrm{ml}$ 에 rubisco 용액 $0.06 \mathrm{ml}$ 를 가하여 $1 \mathrm{ml}$ 의 측정용액으 로 하였다.

UV-VIS spectrophotometer (Scinco S-100)를 이용하여 RuBP가 PGA (3-phosphoglycerate)를 형성하고, 이것이 GAP (glyceraldehydes 3-phosphate)를 형성할 때 산화되는 NADH 양을 $340 \mathrm{~nm}$ 에서 측정하였다. 1 unit는 1 분당 $1 \mathrm{mM} \mathrm{RuBP}$ 를 
분해시키는 효소의 양으로 정의하였다.

\section{Rubisco activase의 활성 측정}

Robinson과 Portis [30]의 방법으로 rubisco activase의 활성 을 측정하였다. $0.4 \mathrm{ml}$ reaction mixture $[50 \mathrm{mM}$ tricine $(\mathrm{pH}$ 8.0) $20 \mathrm{mM} \mathrm{KCl}, 5 \mathrm{mM} \mathrm{MgCl}$, $2.5 \mathrm{mM}$ ATP. $1 \mathrm{mM} \mathrm{PEP,}$ $0.3 \mathrm{mM}$ NADH, 40 units/ml pyruvate kinase, 40 units $/ \mathrm{ml}$ lactate dehydrogenase]에 rubisco activase 용액 $0.4 \mathrm{ml}$ 를 가하 여 $25^{\circ} \mathrm{C}$ 에서 1 분간 반응시킨 다음, $340 \mathrm{~nm}$ 에서 흡광도를 측정 한 후, $\mathrm{ATP}$ 로부터 $\mathrm{ADP}$ 의 생성율을 계산하여 활성을 나타내 었다.

\section{변성제에 의한 rubisco와 rubisco activase의 활성 측정}

L-cysteine, $\beta$-mercaptoethanol, urea, thiourea, guanidium- $\mathrm{HCl}$ 을 사용하여 rubisco와 rubisco acticvase의 활성에 대한 이들 변성제의 영향을 측정하였다. Cd와 SA 및 변성제를 처리하지 않은 대조구의 활성을 100 으로 하여 각 변성제의 활성을 \%로 나타내었다.

\section{결 과}

담배 식물의 생장에 대한 $\mathrm{SA}$ 의 효과와 최적 농도

$\mathrm{SA}$ 의 최적농도를 조사하기 위하여, 기내 배양된 담배 식 물의 줄기를 $10^{-6} \mathrm{mM}-10^{2} \mathrm{mM} \mathrm{SA}$ 가 각각 함유된 MS배지 에서 9 주간 배양하여 각 농도에 따른 담배 식물의 생장을 측 정하였다.
$\mathrm{SA}$ 처리 하지 않은 대조구와 $10^{-6} \mathrm{mM} \mathrm{SA}$ 에서 $10^{-1} \mathrm{mM} \mathrm{SA}$ 처리구에서는 모두 담배 식물의 줄기로부터 식물체가 형성되 었으며, 이 중 $10^{-4} \mathrm{mM} \mathrm{SA}$ 에서 가장 양호하게 생장하였다. 그러나 $1 \mathrm{mM} \mathrm{SA}$ 와 $10 \mathrm{mM} \mathrm{SA}$ 에서는 줄기로부터 약간 잎이 형성되었으나, $10^{2} \mathrm{mM} \mathrm{SA}$ 에서는 완전하게 식물체가 형성되 지 않았다(Fig. 1).

Fig. 1 에서 나타난 결과를 확인하기 위해 각 SA 농도에 따라 배양된 담배 식물의 생체 중량을 측정하였다. $\mathrm{SA}$ 의 농도가 증가할수록 담배 식물의 중량이 증가하여 $10^{4} \mathrm{mM} \mathrm{SA}$ 에서 가장 높은 함량을 보였으며, 이 이상의 농도에서는 농도가 증 가함에 따라 함량은 감소하였다(Fig. 2).

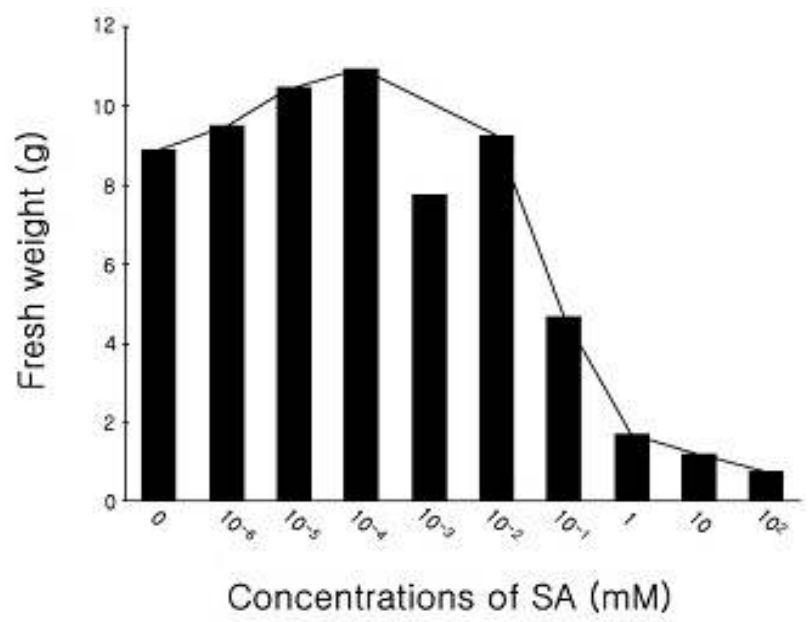

Fig. 2. The fresh weights of tobacco plants grown on MS medium containing $10^{-6} \mathrm{mM}-10^{2} \mathrm{mM}$ SA for 9 weeks.
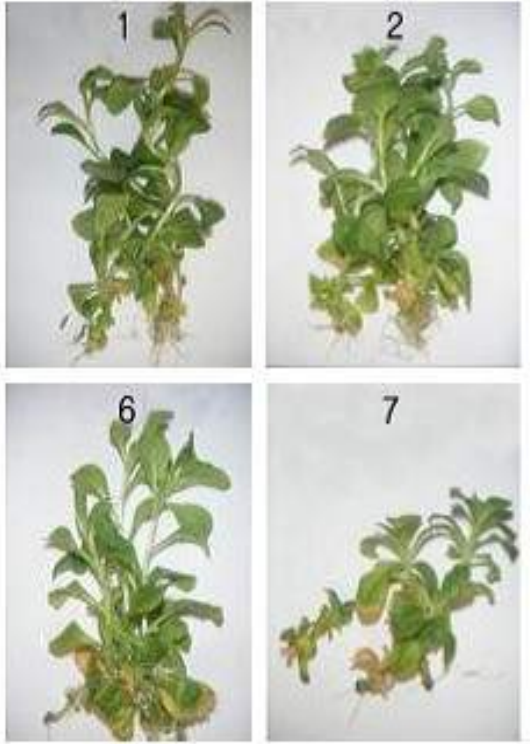

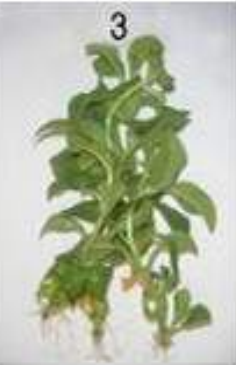

8

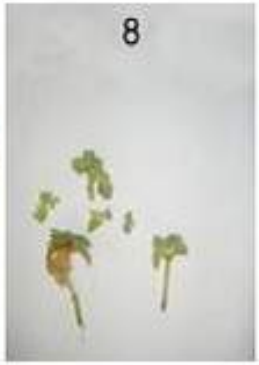

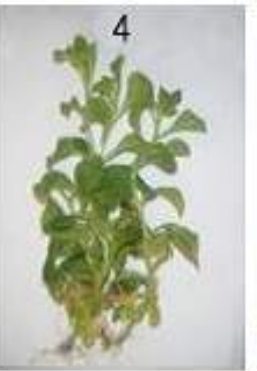
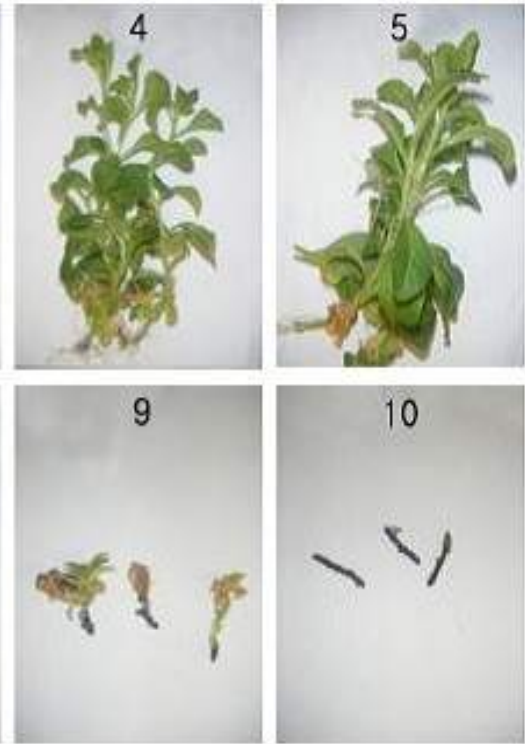

10

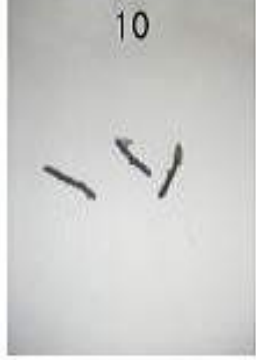

Fig. 1. In vitro induction of tobacco plants on MS medium containing $10^{-6} \mathrm{mM}-10^{2} \mathrm{mM}$ SA for 9 weeks. Plants were grown on MS medium without SA (1), with $10^{-6} \mathrm{mM}(2), 10^{-5} \mathrm{mM}(3), 10^{4} \mathrm{mM}(4), 10^{-3} \mathrm{mM}$ (5), $10^{-2} \mathrm{mM}(6), 10^{-1} \mathrm{mM}$ (7), 1 $\mathrm{mM}(8), 10 \mathrm{mM}(9)$, and $10^{2} \mathrm{mM} \mathrm{SA}(10)$. 

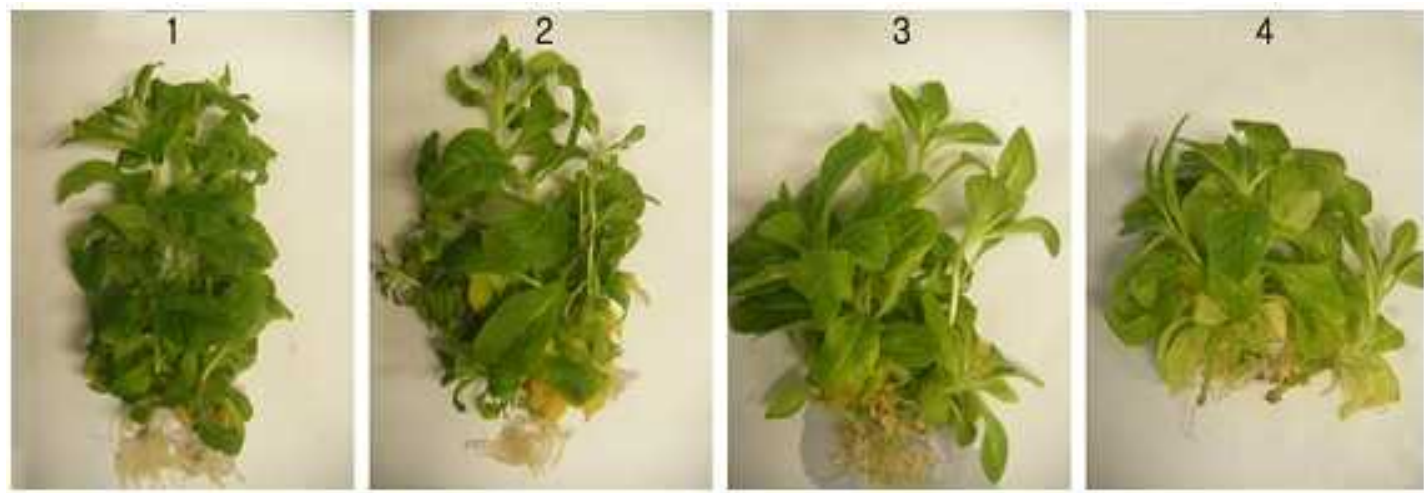

Fig. 3. In vitro induction of tobacco plants grown on MS medium for 11 weeks. Plants were grown on MS medium without Cd and SA (1), with SA (2), Cd (3), and Cd and SA (4). Cd and SA concentration were $0.2 \mathrm{mM} \mathrm{CdCl}_{2} \cdot 2.5 \mathrm{H}_{2} \mathrm{O}$, and $10^{4} \mathrm{mM}$ SA, respectively.

\section{담배 식물의 생장에 대한 카드뮴과 $\mathrm{SA}$ 의 효과}

Fig. 1과 Fig. 2에서 얻은 최적농도인 $10^{4} \mathrm{mM} \mathrm{SA}$ 를 사용하 여, 대조구, SA 처리구, 카드뮴 처리구 및 카드뮴과 SA 혼합 처리구로 구성된 각각의 MS배지 상에 담배 식물 줄기를 배양 한 후, 이들의 생장을 측정하여, 담배 식물의 생장에 미치는 $\mathrm{SA}$ 와 카드뮴의 효과를 조사하였다.

생장은 카드뮴 처리구 < 카드뮴과 SA 혼합 처리구 < 대조구 $<\mathrm{SA}$ 처리구의 순서로서, 대조구와 비교하여 카드뮴 처리구가 낮았으며, 대조구와 SA 처리구를 비교하면 SA가 높게 나타났 다. 또한 카드뮴 처리구와 비교하여 카드뮴과 SA 혼합 처리구 가 높게 나타났으며, 카드뮴 처리구, 카드뮴과 SA 혼합 처리구 및 SA 처리구를 비교함으로써 생장 회복현상을 확인할 수 있 었다(Fig. 3).

Fig. 3에서 나타난 생장의 결과를 확인하기 위해, 각 실험구 에 대한 담배 식물 전체와 잎의 생체 중량을 측정하였다. 담배 식물과 잎 생체중량은 대조구가 각각 5.757 과 $33.9 \mathrm{~g}, \mathrm{SA}$ 처리 구가 6.425 와 $35.7 \mathrm{~g}$, 카드맘 처리구가 3.665 와 $26.8 \mathrm{~g}$, 카드뮴과 $\mathrm{SA}$ 혼합 처리구가 3.698 과 $28.5 \mathrm{~g}$ 으로써(Table 1), 카드뮴 처리 구 < 카드뮴과 SA 혼합구 처리구 < 대조구 < SA 처리구의 순서를 보여 Fig. 3의 결과와 일치하였다.

\section{엽록소에 대한 카드뮴과 $S A$ 의 효과}

광합성 색소인 엽록소에 미치는 카드뮴과 $\mathrm{SA}$ 의 효과를 하

Table 1. Effect of $\mathrm{Cd}$ and SA on growth of tobacco plants

\begin{tabular}{lcc}
\hline & fr. wt./plant (g) & fr. wt./leaf (g) \\
\hline Control $^{1}$ & 5.757 & 33.9 \\
$\mathrm{SA}^{2}$ & 6.425 & 35.7 \\
$\mathrm{Cd}^{3}$ & 3.665 & 26.8 \\
$\mathrm{Cd}+\mathrm{SA}$ & 3.698 & 28.5 \\
\hline
\end{tabular}

${ }^{1}$ no treated with $\mathrm{Cd}$ and $\mathrm{SA}$

${ }^{2} 10^{-4} \mathrm{mM} \mathrm{SA}$

${ }^{3} 0.2 \mathrm{mM} \mathrm{CdCl} \cdot 2.5 \mathrm{H}_{2} \mathrm{O}$
기 위해, 4 개의 각 실험구에 대한 엽록소 $\mathrm{a}$ 와 $\mathrm{b}$ 의 함량을 측정 하였다. 엽록소 $\mathrm{a}$ 와 b 및 전체 엽록소 함량은 대조구가 각각 $13.03,20.53,33.56 \mathrm{mg} / \mathrm{g}$, SA 처리구가 $13.2,20.6,33.78 \mathrm{mg} / \mathrm{g}$, 카드뮴 처리구가 $13.5,13.79,27.30 \mathrm{mg} / \mathrm{g}$, 카드뮴과 SA 혼합 처리구가 13.37, 15.37, $28.94 \mathrm{mg} / \mathrm{g}$ 으로써(Table 2), 엽록소 a에 서 약간의 차이가 있었으나, 전체 엽록소 함량은 카드뮴 처리 구 < 카드뮴과 $\mathrm{SA}$ 혼합구 < 대조구 < SA 처리구의 순서를 보였으며, 카드뮴에 의한 엽록소의 억제를 SA가 회복시켰음 을 알 수 있었다.

\section{Rubisco의 함량과 활성에 대한 카드뮴과 $S A$ 의 효과}

Rubisco에 미치는 카드뮴과 SA의 효과를 조사하기 위해, 4 개의 각 실험구에서 생장시킨 담배 식물의 잎으로부터 $\mathrm{ru}-$ bisco를 분리한 결과, $280 \mathrm{~nm}$ 에서의 흡광도 peak와 활성의 peak가 한 분획에서 일치하여, 이 분획을 rubisco의 함량과 활성 측정에 사용하였다.

Rubisco의 함량은 대조구에서는 $0.586 \mathrm{mg} / \mathrm{ml}, \mathrm{SA}$ 처리구 에서는 $0.670 \mathrm{mg} / \mathrm{ml}$, 카드뮴 처리구에서는 $0.432 \mathrm{mg} / \mathrm{ml}$, 카 드뮴과 SA 혼합 처리구에서는 $0.470 \mathrm{mg} / \mathrm{ml}$ 로서(Fig. 4), 카드 뮴 처리구 < 카드뮴과 SA 혼합구 < 대조구 < SA 처리구의 함량 순서를 보였다. SA 처리한 것과 카드뮴을 처리한 것이 각각 최고와 최저치를 보였으며, 대조구와 비교하여 $\mathrm{Cd}$ 처리

Table 2. Effect of $\mathrm{Cd}$ and SA on chlorophyll contents in tobacco leaves

(mg/g fr. wt.)

\begin{tabular}{lccc}
\hline & Chl a & Chl b & Total chlorophyll \\
\hline Control $^{1}$ & 13.03 & 20.53 & 33.56 \\
$\mathrm{SA}^{2}$ & 13.20 & 20.60 & 33.78 \\
$\mathrm{Cd}^{3}$ & 13.50 & 13.79 & 27.30 \\
$\mathrm{Cd}+\mathrm{SA}$ & 13.37 & 15.37 & 28.94 \\
\hline
\end{tabular}

${ }^{1}$ no treated with $\mathrm{Cd}$ and $\mathrm{SA}$

${ }^{2} 10^{-4} \mathrm{mM} \mathrm{SA}$

${ }^{3} 0.2 \mathrm{mM} \mathrm{CdCl}_{2} \cdot 2.5 \mathrm{H}_{2} \mathrm{O}$ 


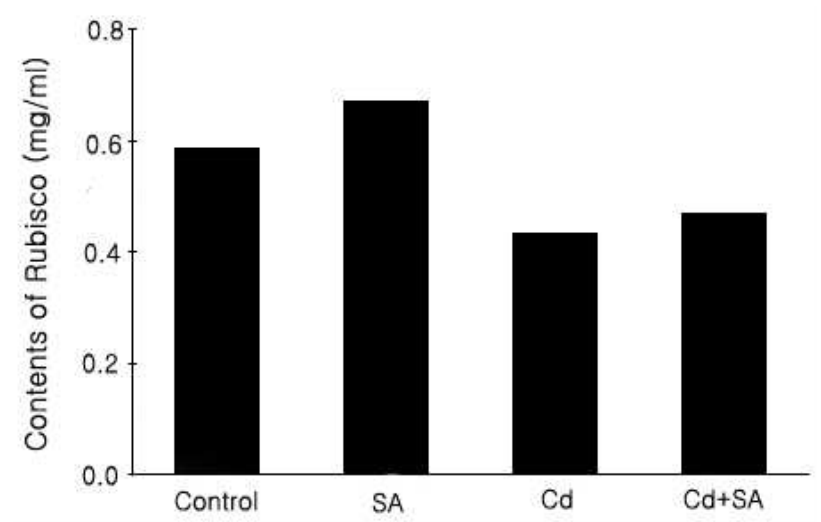

Fig. 4. Effects of $\mathrm{Cd}$ and $\mathrm{SA}$ on contents of rubisco in tobacco leaves. Plants were grown on MS medium without $\mathrm{Cd}$ and SA, with SA, Cd, and Cd and SA. Cd and SA concentration were $0.2 \mathrm{mM} \mathrm{CdCl} \cdot 2.5 \mathrm{H}_{2} \mathrm{O}$, and $10^{4} \mathrm{mM} \mathrm{SA}$, respectively.

구가 낮은 것은 카드뮴이 rubisco의 함량을 억제하였음을 나 타내며, 대조구보다 SA 처리구가 높은 것은 SA가 rubisco의 함량을 촉진시켰음을 나타낸다. 또한 카드뮴 처리구와 카드뮴 과 SA 혼합 처리구를 비교하면 카드뮴에 의한 rubisco의 함량 억제를 SA가 회복시켰음을 알 수 있었으며, 카드뮴 처리구, 카드뮴과 SA 혼합 처리구 및 SA 처리구를 비교한 결과, SA가 rubisco의 함량을 개선시키는 작용에 관여함을 알 수 있었다.

Rubisco의 활성을 측정한 결과, 대조구에서는 0.126 $\mathrm{unit} / \mathrm{ml}, \mathrm{SA}$ 처리구에서는 $0.128 \mathrm{unit} / \mathrm{ml}$, 카드뮴 처리구에서 는 $0.116 \mathrm{unit} / \mathrm{ml}$, 카드뮴과 SA 혼합 처리구에서는 0.120 unit/ml로써(Fig. 5), 카드뮴 처리구 < 카드뮴과 SA 혼합 처리 구 < 대조구 < SA 처리구의 활성 순서를 보였다. 대조구보다 카드뮴 처리구가 낮은 것은 카드뮴이 rubisco의 활성을 억제 하였음을 나타내며, 대조구보다 SA 처리구가 높은 것은 SA가

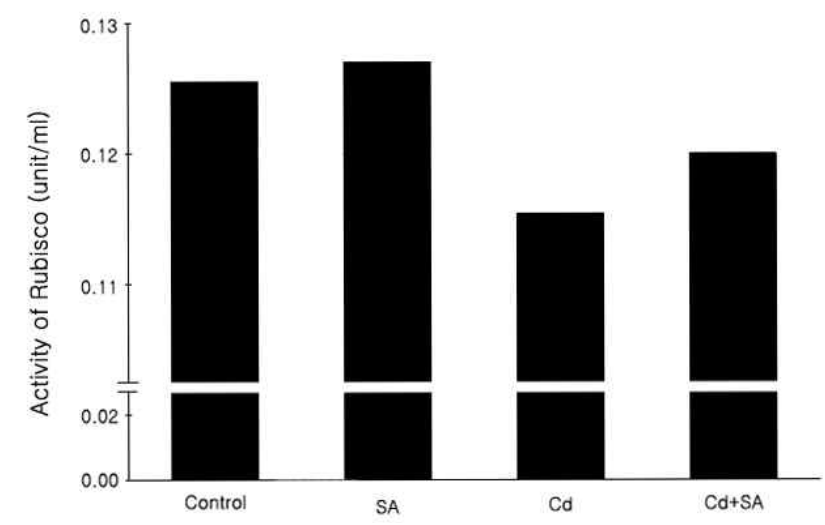

Fig. 5. Effects of $\mathrm{Cd}$ and $\mathrm{SA}$ on activities of rubisco in tobacco leaves. Plants were grown on MS medium without $\mathrm{Cd}$ and SA, with SA, Cd, and Cd and SA. Cd and SA concentration were $0.2 \mathrm{mM} \mathrm{CdCl}_{2} \cdot 2.5 \mathrm{H}_{2} \mathrm{O}$, and $10^{4} \mathrm{mM} \mathrm{SA}$, respectively. rubisco의 활성을 촉진시켰음을 나타낸다. 또한 카드뮴 처리 구와 카드뮴과 SA 혼합 처리구를 비교하면 카드뮴에 의한 rubisco의 활성 억제를 SA가 회복시켰음을 알 수 있었으며, 카드 뮴 처리구, 카드뮴과 SA 혼합 처리구 및 SA 처리구를 비교함 으로써 SA가 rubisco의 활성을 개선시키는 작용에 관여함을 알 수 있었다. 이 rubisco의 활성 결과들은 함량의 결과와 일치 하였다.

Rubisco activase의 함량과 활성에 대한 카드뮴과 $\mathrm{SA}$ 의 효과

Rubisco activase에 미치는 카드뮴과 SA의 효과의 영향을 보기 위하여, 4 개의 각 실험구에서 생장시킨 담배 식물의 잎으 로부터 rubisco activase를 분리하였다. 그 결과, 흡광도와 활 성의 peak가 한 분획에서 일치하여 이를 rubisco activase의 함량과 활성 측정에 사용하였다.

Rubisco activase의 함량을 측정한 결과, 대조구에서는 $0.111 \mathrm{mg} / \mathrm{ml}, \mathrm{SA}$ 처리구에서는 $0.161 \mathrm{mg} / \mathrm{ml}$, 카드뮴 처리구 에서는 $0.104 \mathrm{mg} / \mathrm{ml}$, 카드뮴과 SA 혼합 처리구에서는 0.108 $\mathrm{mg} / \mathrm{ml}$ 로서(Fig. 6), 카드뮴 처리구 < 카드뮴과 SA 혼합구 < 대조구 < SA 처리구의 함량 순서를 보였다. SA 처리한 것과 카드뮴을 처리한 것이 각각 최고와 최저치를 보였으며, 대조 구와 비교하여 카드뮴 처리구가 낮은 것은 카드뮴이 rubisco activase의 함량을 억제하였음을 나타내며, 대조구보다 SA 처 리구가 높은 것은 SA가 rubisco activase의 함량을 촉진시켰음 을 나타낸다. 또한 카드뮴 처리구와 카드뮴과 SA 혼합 처리구 를 비교하면 카드뮴에 의한 rubisco activase의 함량 억제를 $\mathrm{SA}$ 가 회복시켰음을 알 수 있었으며, 카드뮴 처리구, 카드뮴과 $\mathrm{SA}$ 혼합 처리구 및 $\mathrm{SA}$ 처리구를 비교한 결과, SA가 rubisco activase의 함량을 개선시키는 작용에 관여함을 알 수 있었다.

Rubisco activase의 활성을 측정한 결과, 대조구에서는

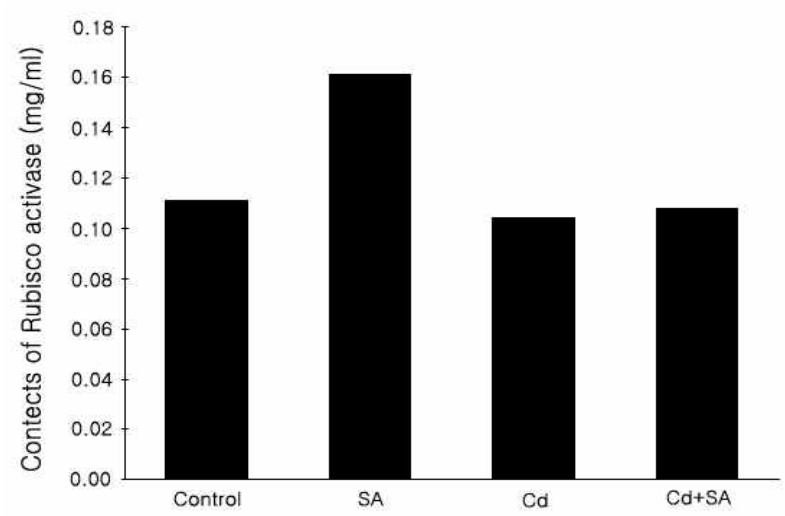

Fig. 6. Effects of $\mathrm{Cd}$ and $\mathrm{SA}$ on contents of rubisco activase in tobacco leaves. Plants were grown on MS medium without $\mathrm{Cd}$ and SA, with SA, Cd, and $\mathrm{Cd}$ and SA. Cd and SA concentration were $0.2 \mathrm{mM} \mathrm{CdCl} \cdot 2.5 \mathrm{H}_{2} \mathrm{O}$, and $10^{-4} \mathrm{mM}$ SA, respectively. 
$0.089 \mathrm{unit} / \mathrm{ml}, \mathrm{SA}$ 처리구에서는 $0.161 \mathrm{unit} / \mathrm{ml}$, 카드뮴 처리 구에서는 $0.078 \mathrm{unit} / \mathrm{ml}$, 카드뮴과 SA 혼합 처리구에서는 $0.085 \mathrm{unit} / \mathrm{ml}$ 로써(Fig. 7), 카드뮴 처리구 < 카드뮴과 SA 혼합 처리구 < 대조구 < SA 처리구의 활성 순서를 보였다. 카드뮴 처리구가 대조구보다 낮은 것은 카드뮴이 rubisco activase의 활성을 억제하였음을 나타내며, 대조구보다 SA 처리구가 높 은 것은 SA가 rubisco activase의 활성을 촉진시켰음을 나타낸 다. 또한 카드뮴 처리구와 카드뮴과 SA 혼합 처리구를 비교하 면 카드뮴에 의한 rubisco activase의 활성 억제를 SA가 회복 시켰음을 알 수 있었으며, 카드뮴 처리구, 카드뮴과 SA 혼합 처리구 및 SA 처리구를 비교함으로써 SA가 rubisco activase 의 활성을 개선시키는 작용에 관여함을 알 수 있었다.

\section{Rubisco의 활성에 대한 변성제의 영향}

대조구, SA 처리구, 카드뮴 처리구 및 카드뮴과 SA 혼합 처리구의 각각 생장시킨 담배 식물의 잎으로부터 분리한 $\mathrm{ru}-$ bisco의 활성에 대한 변성제의 영향을 조사한 결과, 본 연구에 사용한 모든 조절제는 카드뮴 처리구 < 카듬ㅁㅁㄱㅘ $\mathrm{SA}$ 혼합구 < 대조구 < SA 처리구의 순서로 활성이 증가되었으며, 이 순 서는 변성제의 처리 유무와 상관없이 변화가 없었다.

L-cysteine과 $\beta$-mercaptoethanol은 비처리구에 비해 카드 뮴과 SA 처리구가 3-4배 정도 활성이 높게 나와 카드뮴과 SA 조건하에서도 rubisco의 활성을 촉진시켰으며, 특히 $\mathrm{SA}$ 에 대 한 효과가 매우 컸다. Urea와 thiourea는 비처리구에 비해 활 성이 약간 낮게 나타난 반면, guanidium- $\mathrm{HCl}$ 은 매우 낮게 나 타나 rubisco의 활성을 억제시키는 효과가 있음을 알 수 있었 다(Table 3).

\section{Rubisco activase의 활성에 대한 변성제의 영향}

카드뭄과 SA 조건하에서 rubisco activase의 활성에 대한

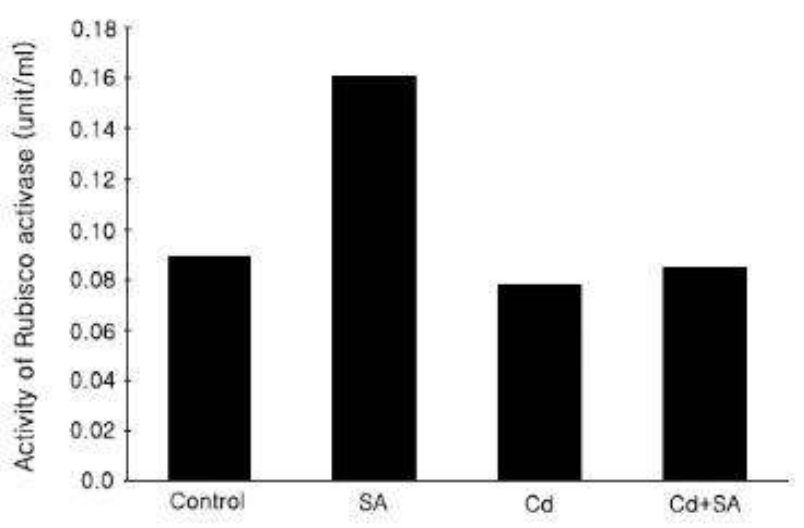

Fig. 7. Effects of $\mathrm{Cd}$ and $\mathrm{SA}$ on activities of rubisco activase in tobacco leaves. Plants were grown on MS medium without $\mathrm{Cd}$ and SA, with $\mathrm{SA}, \mathrm{Cd}$, and $\mathrm{Cd}$ and SA. Cd and $\mathrm{SA}$ concentration were $0.2 \mathrm{mM} \mathrm{CdCl} 2 \cdot 2.5 \mathrm{H}_{2} \mathrm{O}$, and $10^{-4} \mathrm{mM}$ SA, respectively.
Table 3. Effect of denaturants on rubisco activity

\begin{tabular}{lcccc}
\hline & \multicolumn{4}{c}{ Rubisco activity (\%) } \\
\cline { 2 - 5 } & Control $^{1}$ & $\mathrm{SA}^{2}$ & $\mathrm{Cd}^{3}$ & $\mathrm{Cd}+\mathrm{SA}$ \\
\hline No treatment & 100 & 114 & 84 & 87 \\
L-Cysteine & 347 & 375 & 333 & 337 \\
B-Mercaptoethanol & 358 & 382 & 302 & 325 \\
Urea & 96 & 123 & 83 & 86 \\
Thiourea & 92 & 101 & 77 & 80 \\
Guanidium-HCl & 73 & 77 & 70 & 71 \\
\hline
\end{tabular}

${ }^{1}$ no treated with $\mathrm{Cd}$ and $\mathrm{SA}$

${ }^{2} 10^{-4} \mathrm{mM} \mathrm{SA}$

${ }^{3} 0.2 \mathrm{mM} \mathrm{CdCl}_{2} \cdot 2.5 \mathrm{H}_{2} \mathrm{O}$

Table 4. Effect of denaturants on rubisco activase activity

\begin{tabular}{lcccc}
\hline & \multicolumn{4}{c}{ Rubisco activase activity (\%) } \\
\cline { 2 - 5 } & Control $^{1}$ & $\mathrm{SA}^{2}$ & $\mathrm{Cd}^{3}$ & $\mathrm{Cd}+\mathrm{SA}$ \\
\hline No treatment & 100 & 106 & 82 & 99 \\
L-Cysteine & 91 & 111 & 84 & 93 \\
B-Mercaptoethanol & 102 & 119 & 93 & 93 \\
Urea & 79 & 101 & 84 & 91 \\
Thiourea & 104 & 109 & 100 & 106 \\
Guanidium-HCl & 109 & 91 & 91 & 107 \\
\hline
\end{tabular}

${ }^{1}$ no treated with $\mathrm{Cd}$ and $\mathrm{SA}$

${ }^{2} 10^{-4} \mathrm{mM} \mathrm{SA}$

${ }^{3} 0.2 \mathrm{mM} \mathrm{CdCl}_{2} \cdot 2.5 \mathrm{H}_{2} \mathrm{O}$

변성제의 영향을 조사하였다. 대조구, $\mathrm{SA}$ 처리구, 카드뭄 처리 구 및 카드뮴과 SA 혼합 처리구 모두에서 L-cysteine, $\beta$ -mercaptoethanol, urea, thiourea 및 guanidium- $\mathrm{HCl}$ 은 비처 리구와 비교하여 약간 높거나 낮은 수치를 보였으나 큰 차이 가 없어 rubisco activase의 활성에 효과가 없는 것으로 나타났 다(Table 4).

\section{고 찰}

$\mathrm{SA}$ 는 식물체 내에서 합성되는 이차대사 산물이면서 생장 조절제로서 작용하며, 식물에 대한 항병원성 방어물질로써 식 물의 다양한 신호전달 경로 등의 생리적 과정에 중요한 역활 을 하는 것으로 추측되고 있다[8]. 식물의 개화, 뿌리에 의한 이온의 흡수, 기공의 개폐 뿐만 아니라[27], 과일의 성숙 억제 와 굴중성의 조절에도 관여하는 것으로 알려져 있다[36]. 또한 abiotic stress에 대응하는 물질로서의 기능을 하는 것으로도 보고되고 있다[4].

$\mathrm{SA}$ 는 오이 잎에서 산화적 스트레스와 UV-B 저항성에 대한 효과가 있으며[12], 오이 종자의 발아시 삼투 스트레스에 대한 개선 효과 있다고[17] 알려져 있다. 백합에서는 SA가 염발생의 자연적 유도제로서의 역할을 하는 것으로 생각하고 있다[33]. 또한 SA는 카드뮴의 독성에 의해 나타나는 손실효과를 개선 하는 작용을 하는 것으로 보고되고 있다[9]. 
본 연구에서는 카드뮴과 $\mathrm{SA}$ 에 의해 유도되는 담배 식물의 생장, 엽록소 함량, rubisco와 rubisco activase의 함량과 활성 에 대한 결과를 비교하여 카드뮴의 효과에 대한 $\mathrm{SA}$ 의 영향과, 이에 대한 변성제의 효과를 연구하였다. SA는 세포분열의 촉 진과 세포의 팽창을 통해 식물의 생장을 자극하는 효과를 가 지며[33], SA의 농도에 따라 식물의 생장의 양상이 다르게 나 타난다[41]. SA는 식물체내에 존재하는 endogenous 생장조절 제이기 때문에 생장에 미치는 $\mathrm{SA}$ 의 영향을 연구하는 것은 매 우 중요하다. 이에 담배 식물의 생장에 대한 $\mathrm{SA}$ 의 최적농도를 찾기 위하여, $10^{-6} \mathrm{mM}-10^{2} \mathrm{mM} \mathrm{SA}$ 가 각각 함유된 $\mathrm{MS}$ 배지에 서 배양하여 각 농도에 따른 생장을 측정한 결과, $10^{-4} \mathrm{mM}$ $\mathrm{SA}$ 에서 가장 높은 생장을 보였으며, $1 \mathrm{mM}$ 이상에서는 식물체 가 거의 형성되지 않았다. 또한 식물체의 생체 중량도 같은 결과를 보였다. Shakirova 등[33]은 $0.05 \mathrm{mM} \mathrm{SA}$ 는 밀 종자의 발아와 유식물의 생장을 촉진시킨다고 하였다. Shin 등[34]은 $1 \mu \mathrm{M}$ 이하의 농도에서는 포도 현탁배양 세포의 생장은 어떤 영향도 받지 않았으며, $5 \mu \mathrm{M}$ 이상에서는 세포의 생장이 억제 되고, $20 \mu \mathrm{M}$ 에서는 생장이 정지된다고 하였다. 또한 Gutierrez-Coronado 등[11]은 $10^{-8} \mathrm{M}$ 에서 대두의 신초와 뿌리 의 생장이 현저하게 증가한다고 보고하였다 이러한 차이점들 은 식물 재료와 배양 조건이 다르기 때문으로 추측된다.

대조구, SA 처리구, 카드뮴 처리구 및 카드뮴과 SA 혼합 처리구로 구성된 각각의 $\mathrm{MS}$ 배지 상에 담배 식물 줄기를 배양 한 후, 담배 식물의 생장에 대한 카드뮴과 SA의 결과를 비교하 여 카드뮴의 효과에 대한 $\mathrm{SA}$ 의 영향을 연구하였다. 생장은 카드뮴 처리구 < 카드뮴과 SA 혼합 처리구 < 대조구 < SA 처리구의 순서로써, 측정된 식물체와 잎 생체중량의 결과도 같았다. 대조구와 비교하여 카드뮴 처리구가 낮았는데, 이는 카드뮴이 생장을 억제한 결과이며, 대조구와 $\mathrm{SA}$ 처리구를 비 교하면 SA가 생장을 촉진시켰음을 알 수 있었다. 또한 카드뮴 처리구, 카드뮴과 SA 혼합 처리구 및 SA 처리구를 비교한 결 과는 카드뮴에 의해 억제되었던 생장이 SA에 의해 회복되었 음을 보여주고 있다. 대두 유식물 잎에서 카드뮴에 의한 생장 은 SA의 존재 하에서는 현저하게 감소되며, 이는 SA가 카드맘 의 효과를 완화시킨 결과이다[9]. 이는 보리 유식물에서 SA가 카드뮴의 독성을 완화시킨다는 Metwally 등[20]의 결과와 일 치한다.

카드뮴은 엽록소의 합성을 저해하는데[16], 이는 aminolevulinic acid의 합성[38]과 protochlorophyllide 광환원 반응 과 연관되어 있다[3]. 광합성 색소인 엽록소에 미치는 카드뮴 과 $\mathrm{SA}$ 의 효과를 하기 위해, 엽록소의 함량을 측정한 결과, 엽 록소 a에서 약간의 차이가 있었으나, 전체 엽록소 함량은 카드 뮴 처리구 < 카드뮴과 SA 혼합구 < 대조구 < SA 처리구의 순서로 증가하였는데, 이는 카드뮴에 의한 엽록소의 억제를 SA가 회복시켰음을 보여 주고 있다. Drazic과 Mihailovic [9] 은 대두 유식물 잎의 전체 엽록소 함량은 카드뮴에 의해 감소
하며 SA가 존재하여도 카드뮴은 엽록소 함량 감소를 유도한 다고 하여 농도에 따라 SA가 카드뮴에 의한 영향을 감소시키 는 효과가 있음을 보고하였으며, Pancheva 등[24]은 보리 잎에 서 $100 \mu \mathrm{M}-1 \mathrm{mM} \mathrm{SA}$ 에 의해 엽록소 함량이 감소된다고 하여 본 연구 결과와 차이를 보였다.

Catalase, superoxide dismutase, ascorbate peroxidase 및 glutathione reductase와 같은 항산화 효소 수준에서의 $\mathrm{SA}$ 와 카드뮴의 연구가 수행되었으며[6], SA는 식물체내에서 카드뮴 의 독성에 의해 나타나는 손실효과를 완화시키는 것으로 보고 되고 있다. 이와 같이 카드뮴과 같은 중금속에 의한 피해를 줄이는 차원에서 $\mathrm{SA}$ 와 연관하여 광합성의 $\mathrm{CO}_{2}$ 고정반응을 촉매하는 rubisco와 이의 활성화 효소인 rubisco activase에 대한 연구는 매우 중요하다.

이에 본 연구에서는 카드뮴과 SA에 의해 유도되는 rubisco 의 함량과 활성에 대한 자료를 비교하여 카드뮴의 효과에 대 한 $\mathrm{SA}$ 의 영향을 조사한 결과, 카드뮴 처리구 < 카드뮴과 $\mathrm{SA}$ 혼합구 < 대조구 < SA 처리구의 순서로 함량과 활성이 증가하 였다. 대조구와 비교하여 카드뮴 처리구가 낮은 것은 카드뮴 이 rubisco의 함량과 활성을 억제하였음을 나타내는 것으로, rubisco의 활성부위에 존재하는 시스테인의 SH 기에 카드뮴 이 결합하여 이 효소의 활성을 억제하였기 때문이다[37]. 대조 구보다 SA 처리구가 높은 것은 SA가 rubisco의 함량과 활성을 촉진시켰음을 나타낸다. 또한 카드뮴 처리구와 카드뮴과 $\mathrm{SA}$ 혼합 처리구를 비교하면 카드뮴에 의한 rubisco의 함량과 활 성 억제를 SA가 회복시켰음을 알 수 있었으며, 이는 결합되어 있던 카드뮴이 SA에 의해 제거되었기 때문으로 해석된다. 4 개 의 실험구를 비교한 결과는 SA가 rubisco의 함량과 활성을 개선시키는 작용에 관여함을 보여주고 있다.

Rubisco에 대한 카드뮴과 SA의 결과가 rubisco activase와 관련되어 기인되는지의 여부를 밝히기 위해 rubisco activase 의 함량과 활성을 측정한 결과, rubisco의 결과와 같은 순서로 함량과 활성을 보였다. 대조구와 비교하여 카드맘 처리구가 낮은 것은 카드뮴이 rubisco activase의 함량과 활성을 억제하 였음을, 대조구보다 SA 처리구가 높은 것은 SA가 rubisco activase의 함량과 활성을 촉진시켰음을 나타내는 것으로서, 4 개 실험구를 비교함으로써 카드뭄에 의해 억제된 rubisco activase의 함량과 활성이 $\mathrm{SA}$ 에 의해 회복됨으로써 $\mathrm{SA}$ 가 개선 효과가 있음을 의미한다. 이러한 카드뮴에 대한 $\mathrm{SA}$ 의 완화 현상은 보리 유식물[20], 대두 유식물[9]에서 보고되고 있으며, 애기장대 유식물에서 $\mathrm{NaCl}$ 에 의한 손상에 $\mathrm{SA}$ 가 중요한 역할 을 한다는 보고도 있다[4]. Rubisco와 rubisco activase에 대한 결과가 같다는 것은 SA가 독립적으로 각각 rubisco와 rubisco activase 수준에서 작용하기도 하며, 또한 이 두 효소가 연관되 어 작용한다는 것을 의미하는 것으로 해석된다.

효소는 열과 같은 물리적 요인이나 화학적 물질에 의해 변 성되어 활성을 상실하지만 이러한 요인을 제거하면 다시 복귀 
되어 활성을 유지한다. 이 두 작용은 단백질의 3 차 구조를 결 정하는 결합력과 밀접한 관계를 가지고 있다. 이러한 점으로 미루어 보아 본 연구에서의 L-cysteine, $\beta$-mercaptoethanol, urea, thiourea, guanidium- $\mathrm{HCl}$ 은 rubisco와 rubisco activase 의 활성에 영향을 미칠 것으로 사료된다. 카드뮴과 $\mathrm{SA}$ 에 의한 rubisco의 활성과 SA에 의한 카드뮴의 영향에 대한 5 종의 변 성제의 효과를 조사한 결과, 모든 변성제는 카드뮴 처리구< 카드뮴과 $\mathrm{SA}$ 혼합구 < 대조구 < SA 처리구의 순서로 활성을 보였으며, 이 순서는 변성제의 처리 유무와 상관없이 변화가 없었다.

L-cysteine과 $\beta$-mercaptoethanol은 $\mathrm{SH}$ 기를 가지고 있어 S-S 결합을 절단함으로써 변성을 유도하는데, 카드뮴과 SA 조 건하에서도 rubisco의 활성을 촉진시키는 효과를 나타내어 촉 진시키는 결과를 보였으며, 특히 SA에 대한 효과가 매우 컸다. 이는 rubisco의 활성부위의 $\mathrm{SH}$ 기에 결합된 카드뮴[37]의 제거 에 관여하는 $\mathrm{SA}$ 의 작용을 $\mathrm{L}$-cysteine과 $\beta$-mercaptoethanol이 촉진시킨 결과로 추측된다.

Urea, thiourea, guanidium- $\mathrm{HCl}$ 은 단백 질 내에 존재하는 수소결합 보다 더 강하게 단백질과 수소결합을 형성하는 물질 이다. Urea와 thiourea는 비처리구에 비해 활성이 약간 낮게 나타나 효과가 거의 없다. 반면 guanidium- $\mathrm{HCl}$ 은 매우 낮게 나타나 rubisco의 활성을 억제시키는 효과가 있음을 알 수 있 었다. 이는 소수성 상호작용의 파괴에 기인되어 변성이 된 결 과로 추측된다. DTT가 열에 의한 rubisco의 변성에 대해 아주 높은 저항성을 가진다는 보고가 있다[10].

카드뮴과 SA 조건하에서 rubisco activase의 활성이 rubisco와 연관되어 있으므로, rubisco activase의 활성에 대한 변성제의 영향을 조사하였다. L-cysteine, $\beta$-mercaptoethanol, urea, thiourea 및 guanidium- $\mathrm{HCl}$ 은 rubisco activase의 활 성에 효과가 없는 것으로 나타났다. Rubisco activase는 rubisco와는 다르게 변성제에 의해 크게 영향을 받지 않는 것 으로 나타나 변성제가 rubisco activase와 연관되어 rubisco 의 작용에 관여하지 않는 것으로 추측된다. 이는 rubisco activase가 열에 의해 변성된 rubisco의 활성을 회복시킬 수 있는 능력을 가지고 있지 않다고 한 Eckardt와 Portis [10]의 결과와 일치한다.

결론적으로, $\mathrm{SA}$ 는 담배 식물의 기내생장, 엽록소 및 rubisco/rubisco activase에 대한 카드뮴의 손실 효과를 개선 시키는 작용을 하는 것으로 추측되며, 이 작용에 변성제 중 의 일부가 관여하는 것으로 생각된다. 본 연구의 결과는 중 금속에 의한 식물 생장 억제의 개선과 동시에 이 개선 과정 을 전신획득저항성과 연관시킨 연구에 접목할 수 있을 것으 로 사료된다.

\section{감사의 글}

본 연구는 2010년도 계명대학교 비사연구기금으로 이루어
졌음.

\section{References}

1. Alvarez, M. E. 2000. Salicylic acid in the machinery of hypersensitive cell death and disease resistance. Plant Mol. Biol. 44, 429-442.

2. Barcelo, J., Vazquez, M. D. and Poschenrieder, C. 1988. Cadmium-induced structural and ultrastructural changes in the vascular system of bush bean stems. Bot. Acta 101, 254-261.

3. Bödddi, B., Oravecz, A. R. and Lehoczki, E. 1995. Effect of cadminm on organization and photoreduction of protochlorophyllide in dark-grown leaves and etioplast inner membrane preparations of wheat. Photosynthetica 31, 411-420.

4. Borsani, O., Valpuesta, V. and Botella, M. A. 2001. Evidence for a role of salicylic acid in the oxidative damage generated by $\mathrm{NaCl}$ and osmotic stress in Arabidopsis seedlings. Plant Physiol. 126, 1024-1030.

5. Chandra, A. and Bhatt, R. K. 1998. Biochemical and physiological response to salicylic acid in relation to the systemic acquired resistance. Photosynthetica 35, 255-258.

6. Chen, Z., Ricigliano, W. and Klessig, D. F. 1993. Purification and charaterization of a soluble salicylic acid-binding protein from tobacco. Proc. Natl. Acad Sci. USA 90, 9533-9537.

7. Choudhary, M., Bailey, L. D. and Grant, C. A. 1994. Effect of zinc on cadmium concentration in the tissue of durum wheat. Can. J. Plant Sci. 74, 549-552.

8. Delaney, T. P., Uknes, S., Vernooij, B., Friedrich, L., Weymann, K., Negrotto, D., Gaffney, T., Gut-Rella, M., Kessmann, H., Ward, E. and Ryals, J. 1994. A central role of salicylic acid in plant disease resistance. Science 266, 1247-1250.

9. Drazic, G. and Mihailovic, N. 2005. Modification of cadmium toxicity in soybean seedlings by salicylic acid. Plant Sci. 168, 511-517.

10. Eckardt, N. A. and Portis, Jr. A. R. 1997. Heat denaturation profiles of ribulose 1,5-bisphosphate carboxylase/oxygenase (rubisco) and rubisco activase and the inability of rubisco activase to restore activity of heat-denaturated rubisco. Plant Physiol. 113, 243-248.

11. Gutierrez-Coronado, M. A., Trejo-Lopez, C. and LarqueSaavedra, A. 1998. Effects of salicylic acid on the growth of roots and shoots in soybean. Plant Physiol. Biochem 36, 563-565.

12. Hong, J. H. and Kim, T. Y. 2007. Effects of salicylic acid on oxidative stress and UV-B tolerance in cucumber leaves. J. Environ. Sci. 16, 1345-1353.

13. Inskeep, W. P. and Bloom, P. R. 1985. Extinction cofficients of chlorophyll a and b in $N, N$-dimethylformamide and $80 \%$ acetone. Plant Physiol. 77, 483-485.

14. Kang, H. M. and Saltveit, M. E. 2002. Chilling tolerance of maize, cucumber and rice seedling leaves and roots are differentially affected by salicylic acid. Physiol. Plant 115, 
571-576

15. Kneer, R. and Zenk, M. H. 1991. Phytochelatins protect plant enzymes from heavy metal poisoning. Phytochemistry 31, 2663-2667.

16. Larsson, E. H., Bornman, J. F. and Hakan, A. 1998. Influence of UV-B radiation and $\mathrm{Cd}^{2+}$ on chlorophyII fluorescence, growth and nutrient content in Brassica napus. J. Exp. Bot. 323, 1031-1039.

17. Lee, G. S., Kim, T. Y. and Hong, J. H. 2002. Salicylic acid and water stress effects on growth and proline of cucumber seedlings. J. Environ. Sci. 11, 1165-1172.

18. Lee, K. R. and Roh, K. S. 2003. Influence of cadmium on rubisco activation in Canavalia ensiformis L. leaves. Biotechnol. Biopro. Bioeng. 8, 94-100.

19. Lee, T. T. and Scoog, F. 1965. Effect of substituted phenols on bud formation and growth of tobacco tissue culture. Physiol. Plant 18, 386-402.

20. Metwally, A., Finkemeier, I., Georgi, M. and Dietz, K.-J. 2003. Salicylic acid alleviates the cadmium toxicity in barley seedlings. Plant Physiol. 132, 272-281.

21. Mishra, A. and Choudhuri, M. A. 1999. Effects of salicylic acid on heavy metal induce membrane degradation mediated by lipooxygenase in rice. Biol. Plant 42, 409-415.

22. Munné-Bosch, S., Penuelas, J. and Llusia, J. 2007. A deficiency in salicylic acid alters isoprenoid accumlation in water-stressed NahG transgenic Arabidopsis plants. Plant Sci. $172,756-762$.

23. Murashige, T. and Skoog, F. 1962. A revised medium for rapid growth and bioassay with tobacco tissue cultures. Physiol. Plant 15, 473-497.

24. Pancheva, T. V., Popova, L. P. and Uzunova, A. N. 1996. Effects of salicylic acid on growth and photosynthesis in barley plants. J. Plant Physiol. 149, 57-63.

25. Panković, D., Plesničar, M., Arsenijević-Maksimović, I., Petrović, N., Sakač, Z. and Kastori, R. 2000. Effects of nitrogen nutrition on phosynthesis in Cd-treated sunflower plants. Ann. Botany 86, 841-847.

26. Racker, E. 1962. Ribulose diphosphate carboxylase from spinach leaves. Methods Enzymol. 5, 266-270.

27. Raskin, I. 1992. Role of salicylic acid in plants. Ann. Rev. Plant Physiol. Mol. Biol. 43, 439-463.

28. Ray, S. D. 1986. GA, ABA, phenolic interaction and control of growth: phenolic compounds as effective modulators of GA-ABA interaction in radish seedlings. Biol. Plant 28, 361-369.

29. Reese, E. N. and Roberts, L. W. 1984. Cadmium uptake and its effects on growth of tobacco cell suspension cultures.
Plant Cell Rep. 3, 91-94.

30. Robinson, S. P. and Portis, A. R. Jr. 1989. Adenosine triphosphate hydrolysis by purified rubisco activase. Arch Biochem Biophys. 268, 93-99.

31. Roh, K. S. and Chin, H. S. 2005. Cadmium toxicity and calcium effect on growth and photosynthesis of tobacco. J. Life Sci. $15,453-460$.

32. Ryals, J. A., Neuenschwander, U. H., Willits, M. G., Molina, A., Steiner, H. Y. and Hunt, M. D. 1996. Systemic acquired resistance. Plant Cell 8, 1809-1819.

33. Shakirova, F. M., Sakhabutdinova, A. R., Bezrukova, M. V., Fatkhutdinova, R. A. and Fatkhutdinova, D. R. 2003. Changes in the hormonal status of wheat seedlings induced by salicylic acid and salinity. Plant Sci. 164, 317-322.

34. Shin, D. H., Yu, S. R. and Choi, K. S. 1995. Effect of salicylic acid on anthocyanin synthesis in cell suspension cultures of Vitis vinifera L. Kor. J. Plant Tissue Culture 22, 59-64.

35. Somashekaraiah, B. V., Padmaja, K. and Praead, A. R. K. 1992. Phytotoxicity of cadmium ions on germinating seedlings of mung bean (Phaseolus vulgarts): involvement of lipid peroxides in chlorophyill degradation. Physiol. Plant 85, 85-89.

36. Srivastava, M. K. and Dwivedi, U. N. 2000. Delayed ripening of banana fruit by salicylic acid. Plant Sci. 158, 87-96.

37. Stiborova, M. 1988. $\mathrm{Cd}^{2+}$ ions affect the quaternary structure of ribulose- 1,5-bisphoshate carboxylase from barley leaves. Biochemia Physiol. Planzen 183, 371-378.

38. Stobart, A. K., Griffiths, W. T., Ameen-Bukhari, I. and Sherwood, R. P. 1985. The effect of $\mathrm{Cd}^{2+}$ on the biosynthesis of chlorophyll in leaves of barley. Physiol. Plant. 63, 293-298.

39. Vahala, J., Keinanen, M., Schutzendubel, A., Polle, A. and Kangasjarvi, J. 2003. Differential effects of elevated ozone on two hybrid aspen genotypes predisposed to chronic ozone fumigation. Role of ethylene and salicylic acid. Plant Physid. 132, 196-205.

40. Vogelli-Large, R. and Wagner, G. J. 1990. Subcellular localization of cadmium and cadmium-binding peptides in tobacco leaves. Plant Physiol. 92, 1086-1093.

41. Wang, D., Karolina, P.-M., Angela, H. C. and Dong, X. 2007. Salicylic acid inhibits pathogen growth in plants through repression of the auxin signaling pathway. Current Biology 17, 1784-1790.

42. Wang, Z. Y. and Portis, Jr. A. R. 1992. Dissociation of ribulose 1,5-bisphosphate bound to ribulose 1,5-bisphosphate carboxylase/oxygenase and its enhancement by ribulose 1,5-bisphosphate carboxylase/oxygenase activase-mediated hydrolysis of ATP. Plant Physiol. 99, 1348-1353. 


\section{초록 : 카드뮴에 의해 유도된 담배 식물의 생장, 엽록소와 rubisco/rubisco activase에 대한 salicylic acid의 전환 효과}

\section{王玉珊· 노광수*}

(계명대학교 생물학과)

카드뮴에 의해 유도되는 담배의 생장, 엽록소 함량, rubisco와 rubisco activase에 미치는 SA의 영향과, 이에 대한 변성제의 효과를 연구하였다. 담배 기내생장에 대한 $\mathrm{SA}$ 의 최적농도를 찾기 위해, $10^{-6} \mathrm{mM}-10^{2} \mathrm{mM} \mathrm{SA}$ 를 처리하여 9주간 생장시킨 결과, $10^{-4} \mathrm{mM} \mathrm{SA}$ 에서 가장 높은 생장을 보였다. SA와 카드뮴을 4 개의 실험구(대조구, $\mathrm{SA}$, 카드뮴, 카드뮴 $+\mathrm{SA})$ 로 하여 생장, 엽록소 함량 및 rubisco와 rubisco activase의 함량과 활성을 측정한 결과, 카드뮴 > 카드뮴 $+\mathrm{SA}$ < 대조구 <SA 순서이었으며, 대조구보다 카드뮴을 처리했을 때 낮았고, 대조구보다 SA에 서 높았으며, 카드뮴 보다 SA에서 높게 나타났다. 이는 카드뮴에 의해 유발된 억제 현상이 SA에 의해 반전되었음 을 의미하는 것으로, SA는 담배 식물의 기내생장, 엽록소 및 rubisco/rubisco activase에 대한 카드뮴의 손실 효과 를 개선시키는 positive effect 작용을 하는 것으로 나타났다. Rubisco의 활성에 대한 변성제 들은 카드뮴 > 카드 뮴 $+\mathrm{SA}<$ 대조구 <SA 순서로 효과를 나타냈으며, 이 중 L-cysteine과 $\beta$-mercaptoethanol은 활성을 촉진시켰으 며, urea, thiourea, guanidium- $\mathrm{HCl}$ 은 억제시켰다. 이는 L-cysteine과 $\beta$-mercaptoethanol은 변성에 관여하지 않으 며, urea, thiourea, guanidium- $\mathrm{HCl}$ 은 변성에 관여하였음을 의미한다. Rubisco activase의 활성에 대한 변성제들 의 영향을 조사한 결과, 5 종 모두는 비처리구와 비교하여 현저한 영향은 나타내지 않았다. 